\title{
Article
}

\section{Evaluasi Pengelolaan Aset Daerah Kabupaten Bungo}

\author{
Joko Setyoko ${ }^{{ }^{*}}$, Ardjunaidi ${ }^{2}$
}

This article is an open access article distributed under the terms and conditions of the Creative Commons Attribution-ShareAlike 4.0 International (CC BY SA ) License https://creativecommo ns.org/licenses/by$\underline{\text { sa } / 4.0 /)}$.

\section{Jurnal Politik dan} Pemerintahan Daerah ISSN 2686-2271

Fakultas Ilmu Sosial dan Ilmu Politik, Universitas Muara Bungo Jl. Diponegoro No. 27, Muara Bungo-Jambi, (0747) 323310

\author{
${ }^{1}$ Program Studi Ilmu Pemerintahan Fakultas Ilmu Sosial Dan Ilmu Politik, Universitas \\ Muara Bungo, Kabupaten Bungo, Provinsi Jambi \\ ${ }^{2}$ Program Studi Ilmu Pemerintahan Fakultas Ilmu Sosial Dan Ilmu Politik, Universitas \\ Muara Bungo, Kabupaten Bungo, Provinsi Jambi \\ *Correspondence Author: leohisbullah@gmail.com
}

Abstract: Regional assets are an important resource for local governments. Therefore, it is important for local governments to be able to manage assets adequately. In asset management, regional governments must take into account the aspects of planning needs and budgeting, procurement, receipt, storage and distribution, use, business loans, utilization or use, security and maintenance, assessment, elimination, transfer, guidance, supervision and control, financing and demands for compensation so that regional assets are able to provide optimal contributions to the regional government concerned. The location of this research was carried out at the BP2RD Kab. Bungo Region Bungo Jambi Regency, because at BP2RD Kab. Bungo has many Bungo Regency Government Assets for activities or services in the context of dealing with fire disasters. This research will be conducted from January 2018 to March 2018. Goods Management at BP2RD Kab. Bungo. a. Funding. In the management of goods owned by each official office or agency has funds in the management. However, the funds used and the management are sufficient or not. Procurement of goods belonging to BP2RD Bungo Regency. Procurement is an activity to obtain goods or services in a transparent, effective, and efficient manner in accordance with the needs and desires of users. Usage.Usage comes from the root word use. Usage has meaning in a noun or noun class so that usage can express the name of a person, place, or all things and everything that is objectified. The factors that influence the poor management of goods in BP2RD Kab. Bungo Bungo Regency, Coordination between SKPD. The definition of coordination is an activity carried out by many parties from one equal organization and to achieve a common goal with the agreement of each party so that there are no errors in working either disturbing one party with another party, data collection. Data collection means that in this study, the asset data collection carried out by BPKAD is not appropriate

Keywords: Management, Assets, Region

Abstrak: Aset daerah merupakan sumberdaya penting bagi pemerintah daerah. Oleh karena itu, penting bagi pemerintah daerah untuk dapat mengelola aset secara memadai. Dalam pengelolaan aset, pemerintah daerah harus menggunakan pertimbangan aspek perencanaan kebutuhan dan penganggaran, pengadaan, penerimaan, penyimpanan dan penyaluran, penggunaan, piñata usahaan, pemanfaatan atau penggunaan, pengamanan dan pemeliharaan, penilaian, penghapusan, pemindahtanganan, pembinaan, pengawasan dan pengendalian, pembiayaan dan tuntutan ganti rugi agar aset daerah mampu memberika kontribusi optimal bagi pemerintah daerah yang bersangkutan. Lokasi penelitian ini dilakukan di Instansi BP2RD Kab. Bungo Daerah Kabupaten Bungo Jambi, karena pada BP2RD Kab. Bungo terdapat banyak Aset Pemerintah Kabupten Bungo untuk kegiatan ataupun Dinas dalam rangka mengatasi bencana kebakaran. Penelitian ini akan dilakukan mulai dari januari 2018 sampai dengan maret 2018. Pengelolaan Barang di BP2RD Kab. Bungo. a. 
Pendanaan.Dalam pengelolaan barang dimiliki setiap kantor dinas atau instansi memilik dana dalam pengelolaan tersebut. Namun dana yang digunakan dan pengelolaan tersebut cukup atau tidaknyab. Pengadaan barang milik BP2RD Kabupaten Bungo. Pengadaan adalah kegiatan untuk medapatkan barang, atau jasa secara transparan, efektif, dan efisien sesuai dengan kebutuhan dan keinginan penggunanya. Penggunaan.Penggunaan berasal dari kata dasar guna. Penggunaan memiliki arti dalam kelas nomina atau kata benda sehingga penggunaan dapat menyatakan nama dari seseorang, tempat, atau semua benda dan segala yang dibendakan. Faktor-faktor yang mempengaruhi tidak terlaksana pengelolaan barang dengan Baik di BP2RD Kab. Bungo Kabupaten Bungo tersebut, Koordinasi Antar SKPD. Pengertian koordinasi ialah kegiatan yang dikerjakan oleh banyak pihak dari satu organisasi yang sederajat dan untuk mencapai suatu tujuan bersama dengan kesepakatan masing-masing pihak agar tidak terjadi kesalahan dalam bekerja baik mengganggu pihak yang satu dengan pihak yang lainnya, Pendataan. Pendataan maksudnya dalam penelitian ini adalah didalam pendataan asset yang di lakukan BPKAD tidak sesuai

Kata Kunci: Pengelolaan, Aset, Daerah

\section{Pendahuluan}

Pelaksanaan otonomi daerah merupakan suatu harapan cerah bagi pelaksanaan pembangunan secara keseluruhan dimana masing-masing daerah memiliki kesempatan untuk mengelola, mengembangkan dan membangun daerah masingmasing sesuai kebutuhan dan potensi yang dimiliki. Dalam otonomi daerah, pemerintah pusat melepaskan kendali atas fungsi tertentu dan mengalihkan fungsi tersebut menjadi wewenang daerah dan jika perlu, menciptakan lapisan baru pemerintahan (Seymour \& Turner, 2002). Untuk merealisasi pelaksanaan otonomi daerah ini, Dewan Perwakilan Rakyat (DPR) telah menetapkan Undang-Undang No. 22 Tahun 1999 tentang Pemerintah Daerah dan Undang-Undang No. 25 Tahun 1999 tentang Perimbangan Keuangan Pemerintah Pusat dan Daerah. UndangUndang ini kemudian diperbaharui menjadi Undang-Undang No. 32 Tahun 2004 tentang Pemerintah Daerah dan Undang-Undang No. 33 Tahun 2004 tentang Perimbangan Keuangan Antara Pusat dan Daerah.

Sesuai dengan prinsip otonomi yang luas, nyata dan bertanggung jawab serta perimbangan uang yang adil, professional dan transparan antar pemerintah menjadi salah satu tuntutan daerah dan masyarakat. MPR sebagai wakil rakyat menjawab tuntutan tersebut dengan menghasilkan beberapa ketetapan yang harus dilaksanakan oleh pemerintah. Salah satu ketetapan MPR yang dimaksud adalah ketetapan MPR No. XV/MPR/1998 tentang penyelenggaraan Otonomi Daerah, pengaturan dan pemanfaatan sumber daya nasional yang berkeadilan, serta keuangan pusat dan daerah.

Untuk merealisasikan pelaksanaan otonomi daerah maka diikuti sebuah perubahan paradigma baru pengelolaaan aset daerah yang ditandai dengan dikeluarkannya Peraturan Pemerintah No. 6 tahun 2006 yang merupakan peraturan turunan Undang-Undang No. 1 tahun 2004 tentang perbendaharaan negara dan pengelolaan aset daerah yang tertib, akuntabel, dan transparan kedepannya. Pengelolaan aset daerah yang professional dan modern dengan mengedepankan good governance disatu sisi diharapkan akan mampu meningkatkan kepercayaan pengelolaan keuangan daerah dari masyarakat/ stakeholder.

Aset daerah merupakan sumberdaya penting bagi pemerintah daerah. Aset adalah salah satu unsur penting yang harus dikelola dengan baik agar mendapatkan 
hasil yang tepat sesuai dengan laporan keuangan daerah (Kolinug et al., 2015). Oleh karena itu, penting bagi pemerintah daerah untuk dapat mengelola aset secara memadai. Dalam pengelolaan aset, pemerintah daerah harus menggunakan pertimbangan aspek perencanaan kebutuhan dan penganggaran, pengadaan, penerimaan, penyimpanan dan penyaluran, penggunaan, piñata usahaan, pemanfaatan atau penggunaan, pengamanan dan pemeliharaan, penilaian, penghapusan, pemindahtanganan, pembinaan, pengawasan dan pengendalian, pembiayaan dan tuntutan ganti rugi agar aset daerah mampu memberika kontribusi optimal bagi pemerintah daerah yang bersangkutan.

Sementara itu, pengertian aset secara umum menurut Siregar (Siregar, 2004) adalah barang (thing) atau sesuatu barang (anything) yang mempunyai nilai ekonomi (economic value), nilai komersial (commercial value) atau nilai tukar (exchange value) yang dimiliki oleh badan usaha, instansi atau individu (perorangan). Istilah properti seringkali melekat dengan istilah lain untuk memberikan pengertian yang lebih jelas secara hukum, yaitu real estate dan real property dimana keduanya mempunyai makna yang berbeda meskipun ada juga yang menyebutnya sebagai sinonim dalam lingkup tertentu. Selanjutnya, Real estate is the physical land and appurtenances affixed to the land, e.g., structure. Real estate bersifat tidak bergerak (immobile) dan berwujud (tangibel), yang termasuk dalam pengertian ini adalah tanah, semua benda yang secara alami sebagai bagian dari tanah, seperti pepohonan dan barang mineral dan juga segala sesuatu yang dibangun oleh manusia seperti bangunan, jaringan dan lain sebagainya.

Real property merupakan kumpulan atas berbagai macam hak dan interest yang ada dikarenakan kepemilikan atas satuan real estate, meliputi hak untuk menggunakan, menyewakan, memberikan kepada orang lain atau tidak. Properti selain sebagai investasi, juga merupakan aset (Witter et al., 2004). Pengertian asset adalah sesuatu yang memiliki nilai. Real estate sebagai komponen utama dari asset daerah, oleh pemerintah daerah selanjutnya harus dapat dimanfaatkan sebagai asset yang produktif dan berguna sehingga berdampak positif dalam pembangunan ekonomi daerah dan kesejahteraan masyarakat. Dalam neraca keuangan daerah asset dapat menjadi modal bila dapat menghasilkan pendapatan. Namun masih banyak daerah yang belum menyadari peran dan potensi pengelolaan aset secara cermat.

Dalam Pasal 3 ayat (2) Peraturan Pemerintah Nomor 6 Tahun 2006 tentang Pengelolaan Barang Milik Negara/Daerah menyebutkan bahwa pengelolaan barang milik negara/daerah meliputi perencanaan kebutuhan dan penganggaran, pengadaan, penggunaan, pemanfaatan, pengamanan dan pemeliharaan, penilaian, penghapusan, pemindahtanganan, penatausahaan, pembinaan, pengawasan dan pengendalian. Sedangkan menurut Peraturan Menteri Dalam Negeri Nomor 17 Tahun 2007 tentang Pedoman Teknis Pengelolaan Barang Milik Daerah, pengelolaan barang milik daerah meliputi; perencanaan kebutuhan dan penganggaran, pengadaan, penerimaan, penyimpanan dan penyaluran, penggunaan, penatausahaan, pemanfaatan, pengamanan dan pemeliharaan, penilaian, penghapusan, pemindahtanganan, pembinaan, pengawasan dan pengendalian, pembiayaan dan tuntutan ganti rugi.

Pengelolaan Aset dalam pengertian yang dimaksud PP No. 6 Tahun 2006 adalah tidak sekedar administrasi semata, tetapi lebih maju berfikir dalam menangani aset daerah, dengan bagaimana meningkatkan efisiensi, efektifitas dan menciptakan nilai tambah dalam mengelola aset daerah. Oleh karena itu, lingkup pengelolaan asset daerah mencangkup Perencanaan kebutuhan dan penganggaran, pengadaan, penerimaan penyimpanan dan penyaluran pemeliharaan, penatausahaan, penggunaan, pemanfaatan, pengamanan, penilaian, penghapusan, pemindahtanganan, pembiayaan, dan tuntutan ganti rugi. Proses tersebut 
merupakan siklus logistik yang lebih terinci yang didasarkan pada pertimbangan perlunya penyesuaian terhadap siklus perbendaharaan dalam konteks yang lebih luas.

Pengelola asset daerah di Badan Pengelolaan Pajak dan Retribusi DAerah (BP2RD). Kondisi dimana belum terinventarisnya Barang Milik Daerah dengan baik sesuai peraturan yang berlaku pada kementrian / lembaga Negara menjadi sasaran dalam penataan dan penertiban Barang Milik Daerah Pasca pemisahan antara Badan Pengelolaan Pajak dan Retribusi Daerah dan Badan Pengelolaan Keuangan dan Aset Daerah. Arahnya dari langkah-langkah penertiban Barang Milik Daerah (inventarisasi dan penilaian) tersebut adalah bagaimana pengelolaan aset daerah disetiap penggunaan barang menjadi lebih akuntabel dan transparan, sehingga aset daerah mampu dioptimalkan penggunaan dan pemanfaatannya untuk menunjang fungsi pelayanan kepada masyarakat.

Tabel: 1 Inventaris Aset

\begin{tabular}{l|l|l|l} 
No & Nama Aset & Kondidisi & Baik \\
& & 4 & Rusak \\
1 & Mobil Dinas & 9 & \\
2 & Motor Dinas & 9
\end{tabular}

Sumber Data. BP2RD Kab. Bungo tahun 2018

Dari tabel di atas membuktikan begitu banyak aset daerah yang di miliki oleh BP2RD Kab. Bungo. Dari keterangan tabel di atas terlihat jelas bahwa hal yang menjadi fokus permasalahan di Kantor BP2RD Kab. Bungo, Pengelolaan Aset BP2RD Kab. Bungo yaitu belum transparansi mengenai laporan aset daerah tersebut, sehingga nilai aset yang sebenarnya sulit di ketahui oleh masyarakat umum. Selain permasalahan tersebut juga terdapat belum akuratnya informasi mengenai pelaporan aset daerah, dalam hal ini data yang di input atau dimasukkan belum menggambarkan kondisi riil barang yang ada, hanya sebagian kecil yang bisa di ketahui bagaimana keadaan aset tersebut, seperti dapat kita lihat dari tabel di atas yang mana kondisi barang yang ada serta keterangan nomor sertifikat, nomor polisi, nomor pabrik dan nomor BPKB belum tercantum dengan lengkap di dalam buku inventaris tersebut.

Kenyataan ini tidak dapat di pungkiri, bahwa keberhasilan pencapaian tujuan organisasi tidak terlepas dari penataan keseluruhan rangkaian subsistem yang terdapat dalam organisasi itu sendiri yang menurut (SP. Siagian, Manajemen Organisasi Hal;448) terdiri atas struktur dan pejabatnya, tujuan yang harus dicapai, proses yang merupakan rangkaian kegiatan organisasi atas sumber-sumber yang dimanfaatkan untuk mencapai tujuan.

Pandangan diatas mengisyaratkan bahwa proses organisasi adalah serangkaian dari seluruh aktivitas organisasi dalam upaya pencapaian tujuan, sedangkan proses organisasi berlangsung berdasarkan sistematika, prosedur dan data kerja yang telah dianalisis sehingga memungkinkan penciptaan efisien tujuan organisasi.

Dengan demikian, mekanisme kerja yang merupakan suatu proses organisasi memiliki arti penting dalam pencapaian tujuan organisasi yang telah ditetapkan seperti halnya dengan pengelolaan aset daerah, sehingga tanpa adanya tata kerja yang baik serta partisipasi dan kerja sama dari seluruh pegawai, maka target yang ditetapkan tidak akan tercapai dengan optimal.

Pengelolaan Aset Daerah yang dilakukan oleh BP2RD Kab. Bungo Kabupaten Bungo belum seutuhnya sesuai dengan Peraturan Daerah Nomor 19 Tahun 2016 tentang Pengelolaan Barang Milik Daerah. Hal ini terlihat jelas dalam proses pengelolaannya masih banyak terdapat kekurangan, seperti terdapat pada proses perencanaan kebutuhan barang milik daerah di kantor BP2RD Kab. Bungo saat 
sekarang ini belum berjalan, baru rencana proses untuk tahun yang akan datang. Dikarenakan daerah baru, jadi baru mulai tahap belajar proses perencanaan kebutuhan barang milik daerah. Belum tersusun sesuai dengan ketersediaan barang milik daerah yang ada. Rencana pembuatan disusun sebelum rencana kerja dan anggaran, jadi frekuensinya diadakan setiap satu tahun anggaran sebelum menyusun rencana kerja dan anggaran tersebut. Berdasarkan latar belakang penulis tertarik ingin melakukan penelitian yang dijadikan karya ilmiah atau skripsi yang berjudul "Evaluasi Pengelolaan Aset Daerah Kabupaten Bungo (Studi Kasus UPTB BP2RD Kab. Bungo Kab. Bungo).”

\section{Pembahasan}

\section{Pengelolaan Barang di Badan Pengelolaan Pajak dan Retribusi Kabupaten Bungo}

Setiap instansi pasti memiliki Aset, baik itu keuangan maupun barang-barang yang dimiliki dan harus dijaga dengan baik. Barang-barang asset mupun inventaris tersebut yang diberikan oleh pemerintah daerah dan dipercaya untuk menjaga barang tersebut. Proses pengelolaan barang inventaris tersebut sebagai berikut:

1. Pendanaan.

Dalam pengelolaan barang dimiliki setiap kantor dinas atau instansi memilik dana dalam pengelolaan tersebut. Namun dana yang digunakan dan pengelolaan tersebut cukup atau tidaknya. Pengajuan kebutahan setiap instansi Kepada Bupati tidak semuanya di Kabulkan oleh pemerintah atau Instansi yang mengatur hal tersebut, namun hanya mempunyai hak untuk mengajukan kepada Dinas terkait untuk permohanan supaya dip roses. Perlengkapan yang ada dikantor BP2RD ini masih kurang inilah yang menghambat pekerjaan di Kantor BP2RD ini menjadi terhambat.

2. Pengadaan barang milik BP2RD Kabupaten Bungo.

Pengadaan adalah kegiatan untuk medapatkan barang, atau jasa secara transparan, efektif, dan efisien sesuai dengan kebutuhan dan keinginan penggunanya. Yang dimaksud barang disini meliputi peralatan dan juga bangunan baik untuk public maupun pribadi. Barang/jasa publik adalah barang yang pengunaannya terkait dengan kepentingan masyarakat banyak baik secara berkelompok maupun secara umum, sedangkan barang/jasa privat merupakan barang yang hanya digunakan secara individual atau kelompok tertentu. Berdasarkan atas penggolongan ini maka suatu barang atau jasa dapat saja dikategorikan atas barang publik tapi dapat juga dikategorikan atas barang privat tergantung pada penggunaannya. Sebagai contoh, mobil bila digunakan untuk usaha angkutan penumpang umum maka dikategorikan sebagai barang publik, tapi bila digunakan untuk kepentingan pribadi maka dikategorikan sebagai barang privat. Terdapat beragam pemahaman terkait dengan public procurement, tergantung pada cara pandangnya. Mengacu pada pengertian umum tentang pengadaan tersebut maka public procurement dapat dipahami dari sudut pandang obyek pengadaan, pelaksana pengadaan, dan sumber dana untuk mengadakan. Kebutuhan di instansi mnegajukannya ke Badan Pengelolaan Aset dan Keuangan Daerah. Instansi tersebut yang memproses kebutuhan yang di Butuhkan setiap Instansi.

3. Penggunaan.

Penggunaan berasal dari kata dasar guna. Penggunaan memiliki arti dalam kelas nomina atau kata benda sehingga penggunaan dapat menyatakan nama dari seseorang, tempat, atau semua benda dan segala yang dibendakan. Penggunaan berarti proses, cara, perbuatan menggunakan sesuatu. Penggunaan barang sering kali salah tidak sesuai dengan seharusnya. Seperti mobil dinas ini gunakan untuk keperluan disaat dinas atau digunakan untuk kebutuhan kantor. Namun tidak kendaraan dinas terkadang digunakan untuk 
kebutuhan pribadi. Sebagian aparatur negara menganggap bahwa barang atau kendaraan yang diberikan pemerintah menjadi milik pribadi. Padahal barang yang diberikan tersebut merupakan barang atau kendaraan yang digunakan untuk keperluan pekerjaan atau kantor. Untuk memudahkan aparatur Negara untuk mengurus tugas Negara.

Faktor-faktor yang mempengaruhi tidak terlaksana pengelolaan barang dengan Baik di BP2RD Kab. Bungo Kabupaten Bungo tersebut.

Faktor-faktor yang memepengaruhi tidak terlaksana pengelolaan barang di kantor BP2RD disebabkan sebagai berikut:

\section{Koordinasi Antar SKPD}

Pengertian koordinasi ialah kegiatan yang dikerjakan oleh banyak pihak dari satu organisasi yang sederajat dan untuk mencapai suatu tujuan bersama dengan kesepakatan masing-masing pihak agar tidak terjadi kesalahan dalam bekerja baik mengganggu pihak yang satu dengan pihak yang lainnya sedangkan menurut James G March dan Herben A Simon pengertian koordinasi ialah sebuah proses atau kegiatan demi mencapai satu kesatuan antara berbagai macam pihak dalam mencapai tujuan bersama. Menurut teori koordinasi, koordinasi merupakan sebuah sinkronisasi atau penyelarasan berbagai pihak dalam berkerja secara tertip dan teratur dalam batasan waktu akan tetapi koordinasi berbeda dengan kerja sama yang membedakannya ialah aktifitas atau kegiatan yang tercipta tidak dari satu sumber. Koordinasi sangat diperlukan dan bekerja, apalagi yang menyangkut dengan pekerjaan atau keperluan di tempat kita bekerja. Masih terjadi kesalahpahaman antar pegawai dalam pengadaan kebutuhan atau keperluan kantor. Di sini sangat di perlukan koordinasi antas aparatur pemerintah tentang apa yang dibutuhkan untuk melengkapai kekurangan yang ada dikantor tempat dia bekerja.

2. Pendataan.

Pendataan maksudnya dalam penelitian ini adalah didalam pendataan asset yang di lakukan BPKAD tidak sesuai. Di Badan pengelolaan Pajak dan Retribusi Daerah BArang Rusaak atau tudak ada namun di laporat BKAD ada. Ini menjadi tanggung jawab dari kami bagaimana barang tersebut harus ada. Pendataan aset sering dilakukan oleh BAdan Pengelola Keuangan dan Aset Daerah tidaak sesuai dengan laporan yang ada. Pada saat BPKAD meneliti ada tidaknya barang dikantor ini. Terkadang kami menjadi kwalahan karena barang tersebut memang tidak ada.

\section{Penutup}

Kesimpulan yang didapat dalam penelitian ini adalah 1) Pengelolaan Barang di Badan Pengelolaan Pajak dan Retribusi Daerah Kabupaten Bungo yang termasuk a. Efisiensi dan efektifitas pendanaan dalam pengelolaan barang setiap kantor dinas atau instansi masih belum terwujud; b.Pengadaan barang milik Badan Pengelolaan Pajak dan Retribusi Daerah Kabupaten Bungo. masih belum dilakukan secara transparan, efektif, dan efisien sesuai dengan kebutuhan dan keinginan penggunanya. 2) Faktor-faktor yang mempengaruhi tidak terlaksana pengelolaan barang dengan Baik di Badan Pengelolaan Pajak dan Retribusi Daerah Kab. Bungo Kabupaten Bungo tersebut adalah a. Koordinasi Antar dari satu organisasi yang sederajat dan untuk mencapai suatu tujuan bersama masih belum sesuai dengan peraturan perundang-undangan, agar tidak terjadi kesalahan dalam bekerja baik mengganggu pihak yang satu dengan pihak yang lainnya; b. Pendataan asset yang 
dilakukan Badan Pengolalaan Pajak dan Retribusi Daerah masih belum sesuai dengan aturan yang berlaku

Saran yang pertama adalah untuk pengelolaan Barang di Badan Pengelolaan Pajak dan Retribusi Daerah Kabupaten Bungo a. Wujudkan Efisiensi dan efektifitas pendanaan dalam pengelolaan barang setiap kantor dinas atau instansi;b. Pengadaan barang milik Badan Pengelolaan Pajak dan Retribusi Daerah Kabupaten Bungo. masih belum dilakukan secara transparan, efektif, dan efisien sesuai dengan kebutuhan dan keinginan penggunanya. Yang kedua adalah mengenai faktor-faktor yang mempengaruhi tidak terlaksana pengelolaan barang dengan Baik di Badan Pengelolaan Pajak dan Retribusi Daerah Kabupaten Bungo tersebut terdapat a. Lakukan koordinasi Antar dari satu organisasi yang sederajat dan untuk mencapai suatu tujuan bersama dan sesuai dengan peraturan perundang-undangan, agar tidak terjadi kesalahan dalam bekerja baik mengganggu pihak yang satu dengan pihak yang lainnya; b. Melakukan pendataan asset oleh Badan Pengolalaan Pajak dan Retribusi Daerah sesuai dengan aturan yang berlaku.

\section{Referensi}

Budi Winarno.(2012). Kebijakan Publik, Center for Academic Publishing Service (CAPS), Yogyakarta.

Kolinug, M. S., Ilat, V. I., \& Pinatik, S. (2015). Analisis Pengelolaan Aset Tetap Pada Dinas

Pendapatan Pengelolaan Keuangan Dan Aset Daerah Kota Tomohon. Jurnal EMBA: Jurnal

Riset Ekonomi, Manajemen, Bisnis Dan Akuntansi, 3(1).

Margono, S., (2003). Metodologi Penelitian Pendidikan, Jakarta: Rineka Cipta,

Muhammad Ridha Suaib. 2016. Kebijakan Publik, Calpulis, yoyakarta

Purwanto, Erwan Agus dan Dyah ratih Sulistyawati. 2012. Implementasi Kebijakan Publik.

Yogyakarta : Grava Media.

Seymour, R., \& Turner, S. (2002). Otonomi daerah: Indonesia's decentralisation experiment. New Zealand Journal of Asian Studies, 4, 33-51.

Siregar, D. D. (2004). Manajemen Aset. PT. Kresna Prima Persada.

Sugiono, 2010. Metodologi Penelitian Administrasi, Alfabeta : Bandung.

Sugiono. 2012. Metode penelitian kuantitatif kualitatif dan R\&D.Alfabeta : Bandung

Undang-Undang Nomor 5 Tahun 2014 tentang Aparatur Sipil Negara.

Undang-Undang No 19 Tahun 2016 tentang pengelolaan Aset Daerah.

Usman, Husaini dan Purnomo Setiady Akbar. 2011. Metodologi Penelitian Sosial, Bumi Aksara :

Jakarta. 